\title{
Progress towards a national consensus for the SSC?
}

Denver, Colorado

WrTH the process of site selection for the Superconducting Super Collider (SSC) well on its way but signs of money to build it apparently retreating, backers of the huge particle accelerator are concerned not to let political support dwindle as the number of possible sites comes down to a shortlist and then a single eventual winner. But the majority opinion at a meeting of scientists, industrialists and politicians

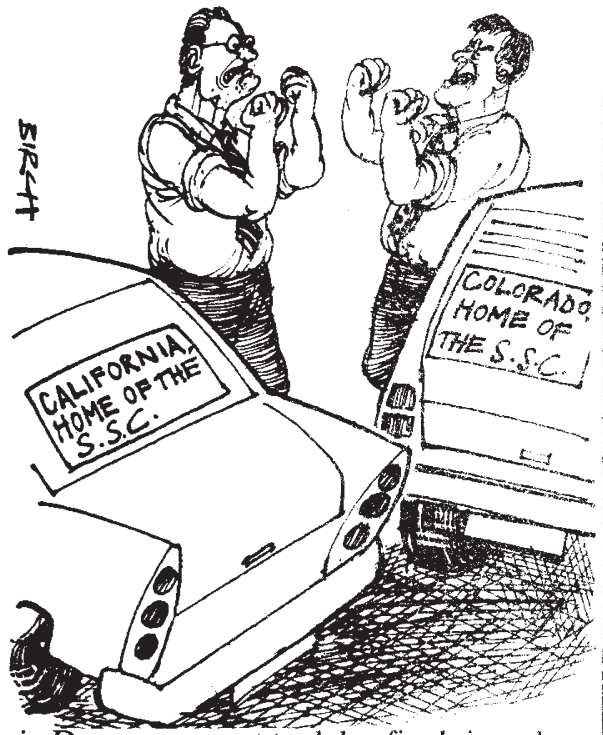

in Denver was not to delay final site selec tion until after authorization of construction, but rather to elicit unconditional expressions of commitment to the SSC as a project of national importance.

The Denver meeting, sponsored by the American Physical Society with the enthusiastic help of the state of Crlorado and its governor, brought together the Secretary of State for Energy, the present as well as the former presidential science adviser, four state governors, one lieutenant governor, three Representatives and a Senator, as well as several influential scientists and science administrators. A prevailing optimistic note, sounding the importance of the SSC for US science. technology and education, was punctuated by warnings concerning the precarious state of current federal budget negotiations, and punctured by Senator Pete Domenici (New Mexico) who, appearing via satellite from Washington said he saw little chance of Congress spending between $\$ 1,000$ and $\$ 2,000 \mathrm{mil}$ lion a year over the next few years, as long as automatic Gramm-Rudman budget reductions were in force.

\section{Correction}

The Japanese attack on Pearl Harbor. Hawaii, was in 1941 (see Nature 330, 515, 1987).
But other speakers, notably John Herrington, Secretary for Energy, and George Keyworth, former science adviser to President Reagan, restored the audience by declaring that the SSC could inject new encrgy into the ailing research base of the United States and thus boost industrial competitiveness.

Some partisan groups were in evidence, particularly prominent being 'Farmers for the SSC in California', who were at pains to stress that local opposition in their state was due to a vocal minority. But lawsuits have been filed to keep the SSC out of California, and a cloud undoubtedly hangs over that bid.

Amid the cheerleading, Herrington had a confused message on international collaboration, saying that the United States should seek financial help from outside, but at another point remarking that New York's proposed site crossing into Canada was dismissed from the competition because "this is an American project". The slogan of the meeting was "can America afford not to build the SSC?", and the issue of international help, which the Department of Energy has never wholeheartedly pursued, seemed to be an unwelcome guest at the party.

David Lindley

\section{UK nuclear operators unhappy with radiation dose advice}

\section{London}

Nuclear power operators in Britain are understood to be still smarting from the decision of the National Radiological Protection Board (NRPB) not to delay publication of new guidelines on radiation dose limits which are likely to form the basis of more stringent safety regulations.

last month, the NRPB published interim guidelines based on preliminary reassessment of the incidence of cancer in survivors of the atomic bomb blasts at Hiroshima and Nagasaki (see Nature 330 , 30; 1987). Some sections of the nuclear power industry are thought to be unhappy that the NRPB has issued guidelines in advance of an expected recommendation by the International Commission on Radiological Protection (ICRP). When it became known that the NRPB was to publish interim guidelines, private, high-level representations were made to the NRPB, but were apparently ignored.

The NRPB recommends that the permitted exposure of workers be cut from 50 millisieverts ( $\mathrm{mSv}$ ) to $15 \mathrm{mSv}$, and that of the general public from $1 \mathrm{mSv}$ to $0.5 \mathrm{mSv}$.

The Central Electricity Generating Board, which operates Britain's nuclear power stations, already imposes a dose limit of $10 \mathrm{mSv}$ on its workforce, and so does not anticipate any problems in instituting new regulations. British Nuclear Fuels (BNFL), which operates the reprocessing plant at Sellafield, says that plant and machinery operating since the mid1970 s would be able to meet any new safety requirements. Measures are being discussed that would reduce risk to some 1,000 workers (about 10 per cent of the workforce) who may be exposed to doses greater than the suggested $15 \mathrm{mSv}$ limit. The United Kingdom Atomic Energy Authority (UKAEA) regards the research upon which the NRPB bases its advice as inconclusive; radiation dosage at
UKAEA facilities is kept "as low as reasonably practicable". Of about 8,000 UKAEA radiation workers, 200 received doses in excess of $15 \mathrm{mSv}$ in 1986.

The Health and Safety Commission is currently re-examining radiation control measures in the light of the NRPB's advice, and has set up a Working Group on Ionizing Radiations; any recommendations are likely to take the form of a voluntary code of practice.

Henry Gee

\section{More nuclear safety}

\section{London}

IN a mood of post-Chernobyl safety consciousness, the world's nuclear power station operators have joined forces to "improve the flow of information and maximize safety". The Association of Nuclear Operators comprises more than 150 electricity utilities from 30 countries, producing more than 99 per cent of the world's nuclear-generated electricity.

Since the association was launched in Paris in October, it has been agreed to establish regional centres in Atlanta, Moscow, Paris and Tokyo, with a small coordinating centre based in Austria, Switzerland or Britain.

The association, which will work closely with the International Atomic Energy Agency, is a forum for the exchange of information, to be achieved largely by teams of engineers visiting foreign power stations to observe operating procedures.

According to Lord Marshall, chairman of Britain's Central Electricity Generating Board and the new association's steering committee, emphasis will be placed on "man-machine interactions", where there have been "important differences of philosophy in the past between Europe, the United States and the Soviet Union".

Simon Hadlington 